озкрито т про н лізов но етногеокультурні спекти розподілу з г льноосвітніх шкіл рим 3 мов ми н вч ння. озподіл з г льноосвітніх шкіл риму є не оптим льним й потребує вдоскон лення т, що є н йв жливішим, м є вр ховув ти н ціон льний скл д н селення певного р йону втономії.

лючові слов : втономн еспублік рим, з г льноосвітні н вч льні з кл ди, етногеокультурні спекти, мов н вЧ ння.

втономн еспублік рим ( ) є дуже в жливим, перспективним, ле й скл дним регіоном кр їни. римський регіон оптим льно розгляд ти як єдине ціле, єдину систему. іншому вип дку н с чек є резон нс як у кримському, укр їнському, т к і в міжн родному м сшт 6 х. зн чимо, що пит ння розподілу з г льноосвітніх н вч льних з кл дів, т кож їхній етнокультурний спект, який вплив є н розподіл, н лежить до гум ніт рної скл дової риму. огляду н стурбов ність суспільств , гром дських орг ніз цій, політичних п ртій, т кож н укової еліти вв ж ємо 3 потрібне визн ти освітне пит ння, особливо пит ння з г льноосвітніх н вЧ льних з кл дів т їхній розподіл, кту льним і т ким що, потребує комплексного підходу т вирішення.

ит нням дослідження геопросторових особливостей розміщення з г льноосвітніх н вч льних з кл дів ( ) з неросійською мовою н вч ння у римській втономії після відновлення кр їною у 1991 р. нез лежності ув ги пр ктично не приділяли. еред близьких до цієї теми пр ць н звемо к рту . вець т . едорової « тнічний скл д н селення», поміщену в тл сі втономної республіки рим [4].

ет цього дослідження - виявити з г льні геопросторові особливості розміщення з неросійською, т кож двомовних (укр їнсько-російських), у римській втономії т порівняти розміщення цих з розселенням основних неросійських етносів. ціон льний скл д н селення , згідно з результ т ми першого сеукр їнського перепису 2001 р. т кий, \%: росіяни - 58,5; укр їнці - 24,4; кримські т т ри (кримч ки) - 12,1; білоруси - 1,5; т т ри - 0,5; вірмени -0,4; інші-2,6. результ т ми сеукр їнського перепису, н селення римського регіону є 6 г тоетнічним, оскільки жодний етнос не ст новить пон д $75 \%$ від з г льної кількості н селення рим [2, с. 124].

ур хув нням ф ктор б г тоетнічності освітньо-н укове пит ння з кономірно ст $\epsilon$ центр льним, в жливим т кту льним. ро н лізув вши зміст періодичних вид нь, преси, т кож г сл гром дських орг ніз цій т політичних п ртій, можн дійти висновку, що освітньо-н укове пит ння є одним із центр льних н терен х римської втономії.

(C) молянінов ., 2011 
продовж перших 14 років нез лежності кр їнської держ ви н території риму мовою н вЧ ння в 3 г льноосвітніх н вЧ льних 3 кл д х бул м йже винятково російськ . ише кільк н вч льних $з$ кл дів вели н вч ння укр їнською чи кримсько-т т рською (кримч цькою) мов ми бо м ли кЛ си 3 укр їнською чИ кримч цькою мов МИ Н Вч Ння.

ротягом 2004-2010 рр. вл д римської втономії поч л більш-менш ктивно вирішув ти освітне пит ння. і з ходи д ли певний позитивний ефект, проте безліч освітніх пит нь і досі не вирішені. стин провідників кримч цького н роду з являє н віть про те, що діти кримч цької н ціон льності не м ють в повному обсязі змоги отримув ти освіту рідною мовою.

жливою проблемою є розподіл з різними мов ми н вч ння по території рим. ростежимо нелогічності у розподілі в меж х території рим, тобто в місцях концентр ції укр їнського чи кримч цького н селення відчутн нест ч шкіл 3 відповідною мовою н вч ння.

г лом по кр їні кількість , учнів т мов н вч ння в них н ведено в т блиці.

г льноосвітні н вч льні з кл ди кр їни т їхня мовн структур у 1992-2009 н. pp.

\begin{tabular}{|l|c|c|c|}
\hline \multirow{2}{*}{ ок зник } & \multicolumn{3}{|c|}{ оки } \\
\cline { 2 - 4 } & $1992 / 1993$ & $2000 / 2001$ & $2009 / 2010$ \\
\hline $\begin{array}{c}\text { ількість н вч льних } \\
\text { з кл дів }\end{array}$ & 21027 & 20457 & 19925 \\
\hline ількість учнів у них & 6835331 & 6933234 & 4355119 \\
\hline $\begin{array}{l}\text { ов н вч ння, \%: } \\
\text { укр їнськ } \\
\text { неукр їнськ }\end{array}$ & 51 & 64 & 79 \\
\hline
\end{tabular}

1992/1993 н. р. в укр їнських н вч вся 6835331 учень, з них 3516056 укр їнською мовою; 3267950 - російською; 6384 - молдовською; 278 - кримч цькою; 18767 - угорською; 602 - польською; 25282 - румунською; 12 - слов цькою.

2000/2001н. р. в укр їнських н вч лося 6933234 учнів, з них 4191257 укр їнською мовою; 2685038 - російською; 1079 - молдовською; 32908 - румунською; 20605 - угорською; 993 - польською; 1109 - кримч цькою; 32 - слов цькою; 24 - болг рською.

2009/2010 н. р. в укр їнських н вч лося 4355119 учнів, з них 3555554 - укр їнською; 750727 - російською; 4300 - молдовською; 5592 - кримч цькою; 15918 - угорською; 1401 - польською; 21092 - румунською; 102 - слов цькою; 44 - болг рською.

втономній еспубліці рим ситу ція в освітній сфері к рдин льно відрізняється від з г льноукр їнської. сновн причин - це неоднорідність т конфліктність н ціон льного скл ду втономії, вплив іноземних держ в, мент льн особливість вл дної верхівки, п сивність бо стр х центр льної вл ди кр їни, невизн ченість т інертність кримського суспільств . слідком цих чинників ст ло те, що протягом перших 14 років укр їнської нез лежності м йже не відбув лося змін в освітній сфері риму. йже всі школи риму (99 \%) з 1991 до 1999 р. вели н вч ння російською мовою. иту ція поч л змінюв тися з огляду н тиск центр льної вл ди, з пит римського суспільств т інші чинники. 
ижче н ведено д ні про мовну структуру кримських

по трьох ключових н вч льних рок х з період нез лежності кр їни.

1992/1993 н. р. у кримських н вч лося 307282 учнів, з них 82 укр їнською мовою; 306922 - російською; 278 - кримч цькою.

2000/2001 н. р. у кримських н вч лося 250316 учнів, з них 1612 - укр їнською мовою; 245134 - російською; 3570 - кримч цькою.

2009/2010 н. р. у кримських н вч лося 184940 учнів, з них 2350 - укр їнською; 176998 - російською; 5592 - кримч цькою.

ин мік мовної структури кримських упродовж 1992-2010 рр. у римській втономії пок з н н рис. 1.

ціон льний скл д дміністр тивних р йонів римської втономії є неоднорідним. ідповідно, й освітні процеси т освітня політик щодо окремих р йонів риму повинні бути різном нітними. н ш погляд, для поглибленого н лізу з огляду н геопросторову специфіку, в рто окремо виділити т кі дміністр тивні одиниці рим, с ме: м. імферополь р зом з імферопольським р-ном, ж нкойський р-н, м. вп торія р зом $з$ кським р-ном, хчис р йський $\mathrm{p}-\mathrm{H}$, ілогірський $\mathrm{p}-\mathrm{H}$ т елику лту. н шу думку ці р йони є репрезент тивними т х р ктеризують весь рим.

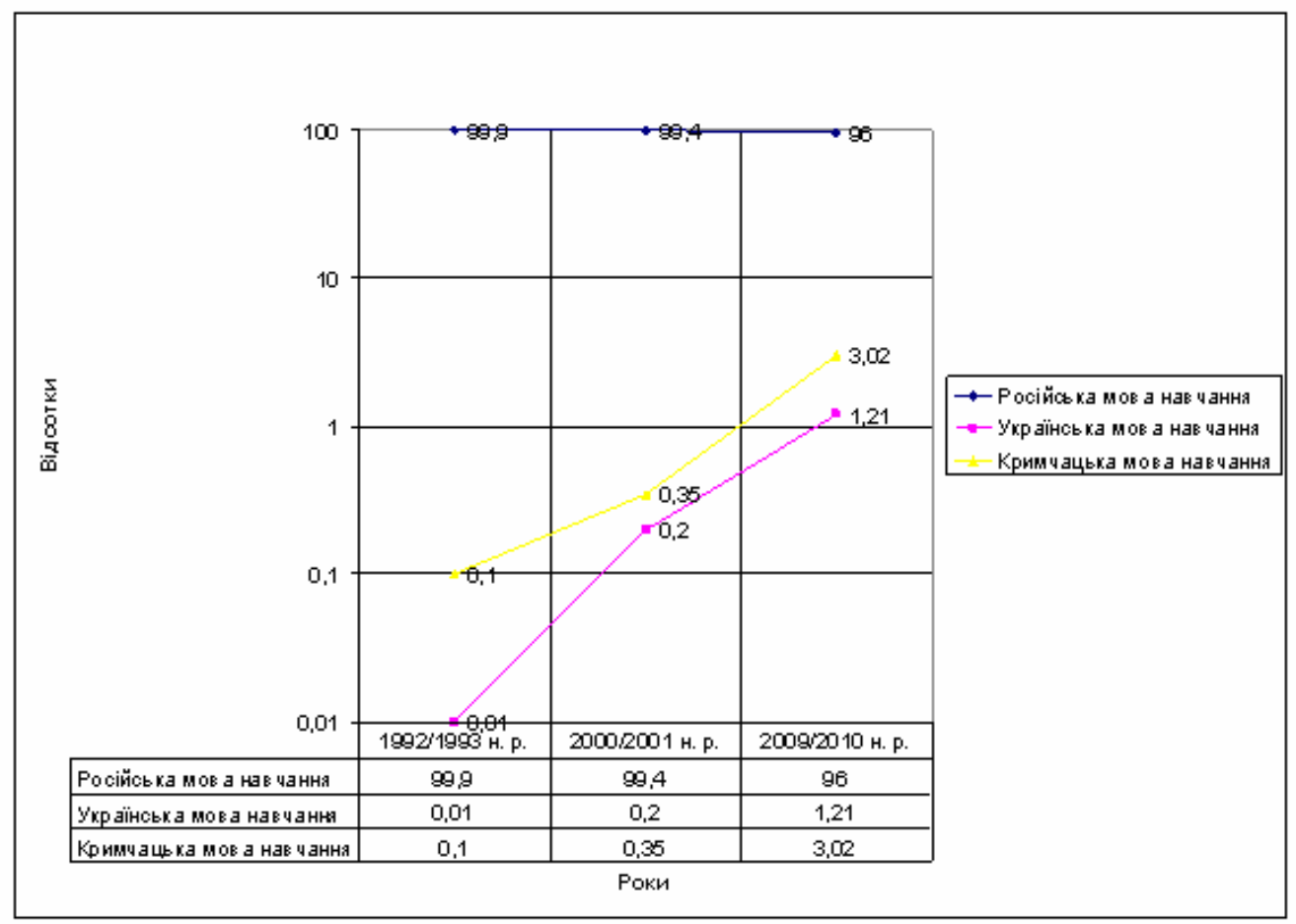

ис. 1. ин мік мовної структури кримських упродовж 1992-2010 pp.

к 3 зн чено вище, протягом трив лого ч су в кримських повністю домінув л освіт російською мовою. 1993 р. відкрито першу школу кримч цькою мовою н вч ння у смт ктябрське (кол. іюк- нл р) р сногв рдійського р-ну. 
1992/1993 н. р. дві школи ст ли двомовними, с ме - російською т укр їнською мов ми н вч ння (обидві в м. імферополі), чотири - 3 російською т кримч цькою мов ми н вч ння (усі чотири школи - в ж нкойському р-ні). 1993/1994 н.p. перепрофільов но ще дві школи у м. імферополі, що ст ли з російською т укр їнською мов ми н вч ння. 1994/1995 н. р. одн школ в м. імферополі з російською мовою н вч ння ст л двомовною, тобто російською т укр їнською мов ми н вч ння; дві школи ж нкойського р-ну з російською мовою н вч ння були перепрофільов ні у двомовні т ст ли з російською т кримч цькою мов ми н вч ння. 1995/1996 н. р. у м. лті дві школи ст ли двомовними, з російською т укр їнською мов ми н вч ння.

2009/2010 н. р. у риму було вісім шкіл з укр їнською мовою н вч ння, с ме в м. лушт - дві; в м. лт - одн ; в м. імферополь т імферопольському р-ні - дві (с. олодіжне т с. омсомольське); у м. еодосія-одн ; в м. ерч-одн ; в смт олкіно енінського р йону - одн (рис. 2).

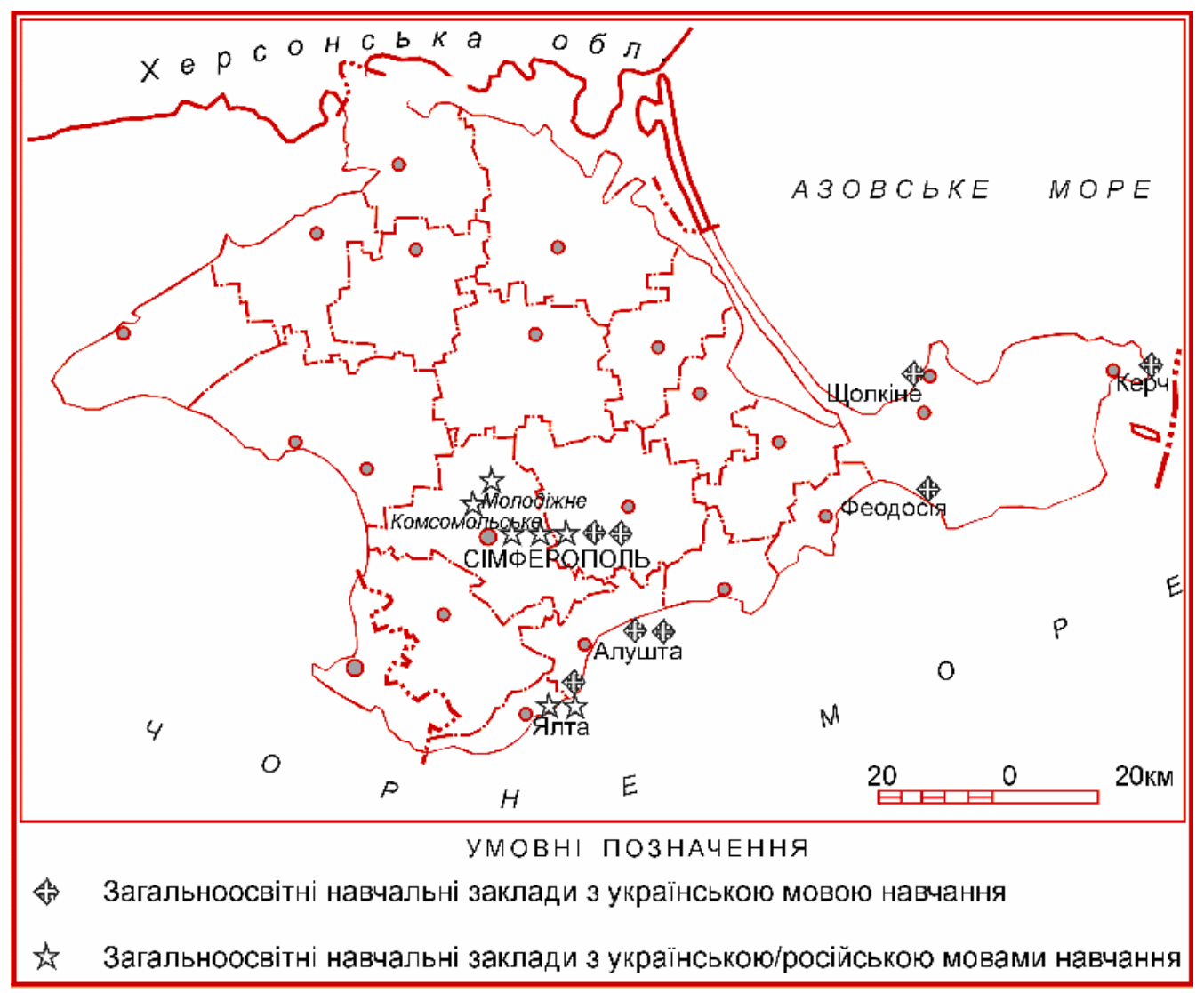

ис. 2. г льноосвітні н вЧ льні з кл ди з укр їнською т укр їнською/російською мов ми н вч ння.

2009/2010 н. р. н лічув лося 16 шкіл з кримч цькою мовою н вч ння, с ме у ілогірському р-ні - три школи(м. ілогірськ, смт уя т с. итвиненкове); ж нкойсь- 
кому р-ні - три (смт зовське, сел річне т йське); м. вп торії-одн ; хчис p йському р-ні - дві (м. хчис р й т с. іліне); т по одній у міст х імферополі, д ку, іровському (м. т рий рим, р сногв рдійському (смт ктябрське) р йон х, смт овєтський - 1; ервом йському р йоні (с. ри- ш) т кському (с. ерес єве) p йон х (рис. 3).

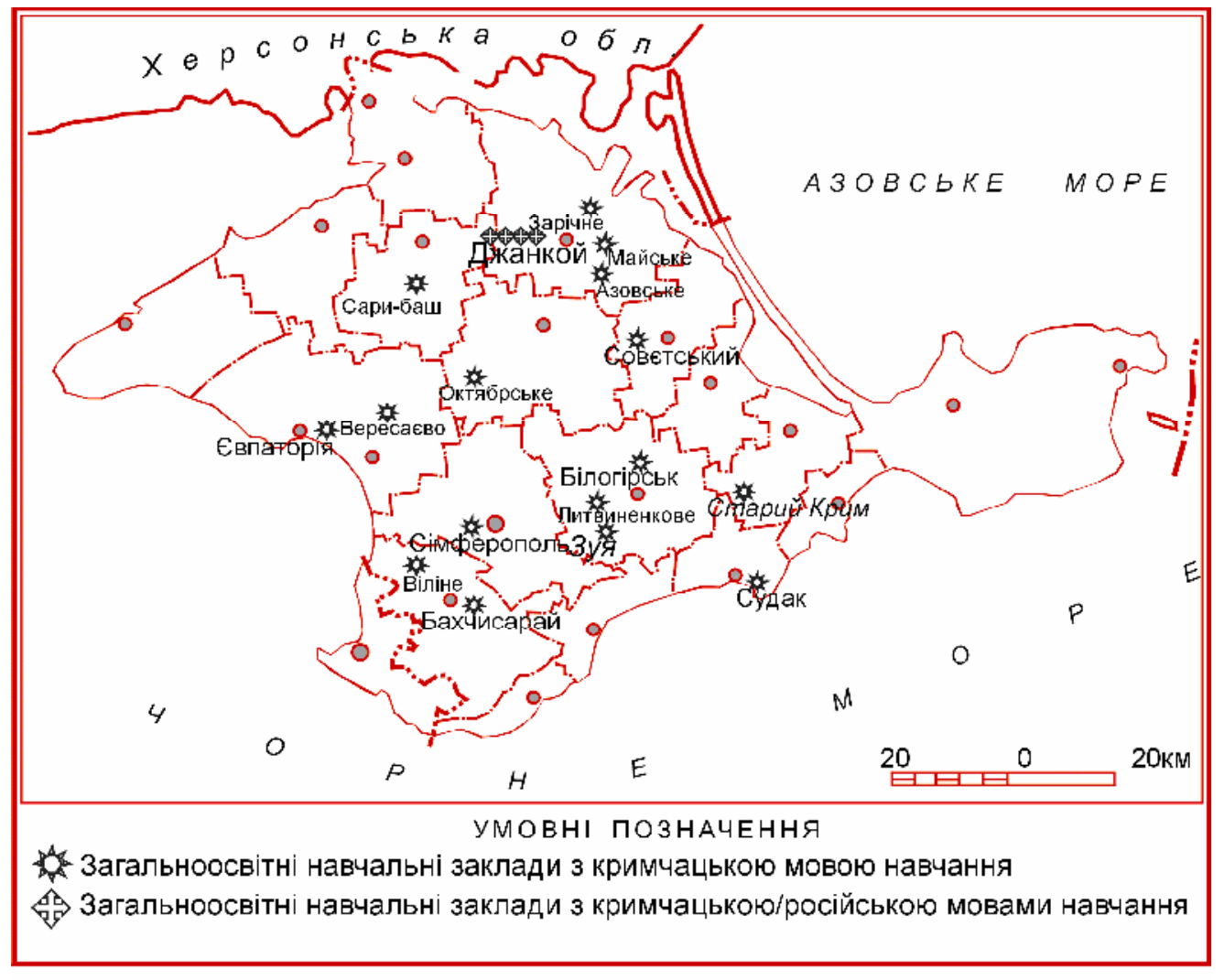

ис. 3. г льноосвітні н вч льні з кл ди з кримч цькою т кримч цькою/російською мов ми н ВЧ ння.

р нсформ ція освітньої системи відбув ється п р лельно з тр нсформ цією суспільств, вл ди т освітнього середовищ . н ш погляд, необхідно оптимізув ти функціонув ння освітньої г лузі в риму. е необхідно викон ти з метою уникнення нег тивних процесів у кримському т укр їнському суспільств х.

озподіл з кл дів освіти в меж $\mathrm{x}$ рим перев жно є не рівномірним т логічним, оскільки в регіон х, де висок концентр ція укр їнців, нем шкіл з укр їнською мовою н вЧ ння ( ж нкойський, р сноперекопський, оздольненський р йони т ін.) ідповідно, простежен нест ч шкіл з кримч цькою мовою н вч ння в р йон х, де 3 фіксов н порівняно велик кількість кримч цького н селення, с ме - імферопольський і ілогірський р йони, м. уд к т ін. [3]. ур хув нням територі льних особливостей риму т кож вд сться оптимізув ти систему 
тже, н н ш погляд освітня систем риму м є грунтув тися перш 3 все н етнічних т культурних особливостях як певного р йону втономії, т к і всього риму. гідно з результ т ми сеукр їнського перепису 2001 р., люди, які визн ли себе укp їнцми з н ціон льністю, перев жно прожив ють у північних р йон х . ле в цих р йон $\mathrm{x}$ риму вз г лі нем шкіл з укр їнською бо з двом мов ми н вч ння. ей ф кт порушує пр в укр їнців н отрим ння середньої освіти рідною мовою, т кож пр в н отрим ння освіти укр їнською мовою інших етнічних груп. кож ув ж ємо, що кількість т лок ліз ція кримч цькою мовою н вч ння є нелогічними. ентр ми комп ктного прожив ння кримч ків є імферопольський, ілогірський, хчис $\mathrm{p}$ йський т уд цький $\mathrm{p}$ йони. ількість шкіл у цих $\mathrm{p}$ йон $\mathrm{x}$ повністю не відповід $\epsilon$ ре льним потреб м, ун слідок чого зн чн кількість кримч ків не м є змоги отрим ти освіту рідною мовою і змушен отримув ти освіту російською.

огляду н н ведене вище вв ж ємо, що пит ння освіти треб вирішув ти зв жено, поступово і з думкою про всі з цік влені сторони, геопросторові особливості риму, з думкою про м йбутне кожної дитини, вр ховуючи з пит б тьків і дітей, т кож 3 г льноукр їнську ситу цію.

в жений т поступовий розвиток освіти в риму передб ч $є з$ лучення вузькопрофільних ф хівців, зокрем економіко-соціогеогр фів, не предст вників певних політичних орг ніз цій, з стосув ння новітніх досягнень у сфері освіти, т кож усіх 3 цік влених сторін.

1. втономн еспублік рим. олітико- дміністр тивн к рт . 1:250 000. . : ртогр фія 2010.

2. овенч $\kappa$. . еогр фія культури : проблеми теорії, методології т методики дослідження / овенч к. ьвів: ,2008. 240 с

3. овенч к.., молянінов . . еопросторові спекти етногеокультурної ситу ції у римській втономії // ч. 3 п. врич. уни-т им. . . ерн дского. ер. еогр фия. 2004. . 17. № 4 . 261-266.

4. вець . ., едоров . . тнічний скл д н селення. 1:1 $800000 / /$ втономн республік рим. тл с. иїв ; імферополь, 2003. . 47

5. т тистичний щорічник кр їни з 2008 рік. . . онсульт нт, 2007. 567 с.

6. http: // www.ukrcensus.gov.ua

\section{ETHNOGEOCULTURAL ASPECTS OF COMPREHENSIVE SCHOOLS ALLOCATION IN THE AUTONOMOUS REPUBLIC OF CRIMEA BASED ON LANGUAGE TEACHING}

\section{S. Smolyaninow}

Ivan Franko National University of Lviv, P. Doroshenko St., 41, UA - 79000 Lviv, Ukraine

In the article it is analyzed ethnogeocultural aspects of comprehensive schools allocation based on the language teaching. Allocation of comprehensive schools in the Autonomous Republic of Crimea is not optimal and needs improvement and have to take into account population ethnic composition of certain district of Crimea.

Key words: The Autonomous Republic of Crimea, comprehensive schools, ethnical-geographicalcultural aspects, language teaching. 


\section{- молянинов}

ьвовский н цион льный университет имени в н р нко, ул. . орошенко, 41, г. ьвов, 79000, кр ин

скрыто и про н лизиров но этногеокультурные спекты р спределения общеобр зов тельных школ рым з язык ми обучения. спределение общеобр зов тельных школ рым не является оптим льным и нужд ется в усовершенствов нии, т кже, что очень в жно, должно учитыв ть н цион льный сост в н селения определенного р йон втономии.

лючевые слов : втономн я еспублик рым, общеобр зов тельные школы, этногеокультурные спекты, язык обучения.

т ття н дійшл до редколегії 16.12.2011 рийнят до друку 19.04.2011 